\title{
Microstructural Evolution of Cantilever Wire Probe after Touch-Down Fatigue Cycles for Power Semi-Conductor Wafer Testing
}

\author{
전력반도체 웨이퍼 검사용 컨틸레버 와이어 프로브의 \\ 피로 주기에 따른 미세조직 변화
}

Won Sik Hong*, ${ }^{*}$ Mi-Song Kim*, and Myeongin Kim*

*Electronic Convergence Materials \& Device Research Center, Korea Electronics Technology Institute, Gyeonggi-do, 13509, Korea

†Corresponding author: wshong@keti.re.kr

(Received November 1, 2021; Revised November 16, 2021; Accepted November 24, 2021)

\begin{abstract}
As fatigue fracture occurs in the bending area of the wire probe of the probe card owing to fatigue load during the touch-down (T/D) test, the development of wire probe materials with improved fatigue properties according to the wire materials is required. In this study, Tungsten (W), Rhenium-Tungsten (ReW), Beryllium-Copper $(\mathrm{BeCu})$, and P7 (Palladium - Silver - Copper alloy, Pd-Ag-Cu) alloy were used to measure the tensile strength of the cantilever wire which was utilized for testing the electrical property of power semiconductor wafers used in the probe card. Additionally, the fatigue characteristics and microstructure changes of the wire were analyzed according to the T/D fatigue test using a scanning electron microscope, and electron back-scattered diffraction analysis was used for comparative analysis. In $\mathrm{W}$ and $\mathrm{ReW}$ wire probes with high initial yield strength, the misorientation angle due to grain elongation was smaller than that of P7. Accordingly, the grain deformation due to strain generation was small, whereas in materials with low initial yield strength, the misorientation angle was smaller. However, the amount of strain generated by grain orientation deformation was large. Therefore, under long-term T/D test conditions, it is assumed that $\mathrm{ReW}, \mathrm{W}$, and $\mathrm{BeCu}$ wire materials, which generate less deformation after long-term use than those with high initial strength, are superior to P7 materials.
\end{abstract}

Key Words: Power semiconductor, Probe card, Cantilever wire probe, EBSD, Touch-down fatigue

\section{Introduction}

Wide-bandgap (WBG) semiconductors based on the compounds silicon carbide $(\mathrm{SiC})$ and gallium nitride $(\mathrm{GaN})$ are recently being commercialized. As with the full-scale development of highly efficient, high-frequency, highly reliable, and high power density power conversion systems (power modules such as inverters and converters) employing these compound semiconductors, the demand for WBG-based power modules is growing. Environmentally-friendly electric vehicles consume higher electric energy in comparison to previous internal combustion engines, for which an increase in the efficiency of power conversion is crucial.
Therefore, a power conversion system such as an inverter or a converter, which converts the direct current (DC) and alternative current (AC) power conversion to the desired phase and frequency by using the properties of the power semiconductor, has become highly critical. Power modules for vehicle parts use high-power $\mathrm{Si}$ or $\mathrm{SiC}$ power semiconductors, for which demands are recently rapidly increasing. Therefore, the development of probe cards for power semiconductors, used in producing high-voltage and high-current power semiconductor elements, is simultaneously proceeded.

A probe card is utilized as a medium for signal transmission during the semiconductor manufactruring process, in the inspection for testing the electrical operation of the individual chips inside completed wafers. The 
probe card is a customized product, which is individually designed and fabricated to satisfy the specifications of the semiconductor for testing. It is classified as a high value-added product because a new probe card needs to be fabricated for each variation in the semiconductor specification. Additionally, the probe card is one of the core components for testing when the entire fabrication process, among the semiconductor production processes, is complete ${ }^{1,2)}$. Regarding the type of probe card for inspecting the state of the electrical operation of the chip inside the wafer, in which a precise line-shaped contact pin (or probe) adheres to the printed circuit board (PCB) of a certain standard. The probe contacts the wafer to serve as a medium between the measurement device and the wafer top surface and determine the fair to bad qualities of all the semiconductor chips. The cantilever wire probe card has long probes, for which evenly fitting the entire length of the probes is difficult. While it may limit high-speed signal transmissions, it is suitable for inspecting high-power and high voltage semiconductor elements such as the power semiconductor element. However, a probe card is repetitively used for wafer inspections, up to tens of thousands of times and with the potential tap (In/Out, I/O) on the surface of the power semiconductor wafer in contact with the wire, so the issue of sustained repetitive fatigue load delivered on the probe card wire arises. Accordingly, a fatigue fracture is generated due to the fatigue load on the bending part of the probe card wire, for which the development of wire materials improved for fatigue characteristics is being demanded. Additionally, the probe card wire during the measurement of the I/O on the wafer surface contacts with the touch-down (T/D) test method, which generates scrubs on the surface of the chip in the upper part of the wafer. Thus, the probe card wire must have outstanding bending strength and fatigue strength. Concurrently, the development of materials that do not cause scrub marks is in demand.

This study used four types of materials, tungsten (W), rhenium-tungsten $(\mathrm{ReW})$, beryllium-copper $(\mathrm{BeCu})$, and palladium-silver-copper alloy $(\mathrm{P} 7, \mathrm{Pd}-\mathrm{Ag}-\mathrm{Cu})$ to measure the tensile strength of the probe card cantilever wire for power semiconductor wafer measurement and to comparatively analyze the fatigue properties of the wire according to the T/D fatigue test and the microstructural variations through the scanning electron microscopy (SEM) and electron back-scattered diffraction (EBSD).

\section{Experimental methods}

\subsection{Cantilever probe wire material}

The material properties and alloy type of the original material for the four types of cantilever wire probes are summarized in Table $1 . \mathrm{W}$ and ReW with high melting points and tensile strengths, and $\mathrm{BeCu}$ and $\mathrm{Pd}-\mathrm{Ag}-\mathrm{Cu}$ alloys with relatively low tensile strengths were used. The SEM images of the wire probes are shown in Fig. 1. The tip diameter of the four wire probes $\mathrm{W}, \mathrm{ReW}, \mathrm{BeCu}$, and $\mathrm{P} 7$ were $118,43,69$, and $118 \mu \mathrm{m}$, respectively.

\subsection{Cantilever wire tensile strength measurement}

The tensile strengths of the four types of wire probes were measured using the Instron 8848 (Instron Co. Ltd., USA) equipment as shown in Fig. 2. The grip with a serrated jaw face for testing the tensile strength was fixed to measure the tensile strength at 2 and 10 $\mathrm{mm} / \mathrm{min}$, and the degrees of influence to the testing velocity were compared.
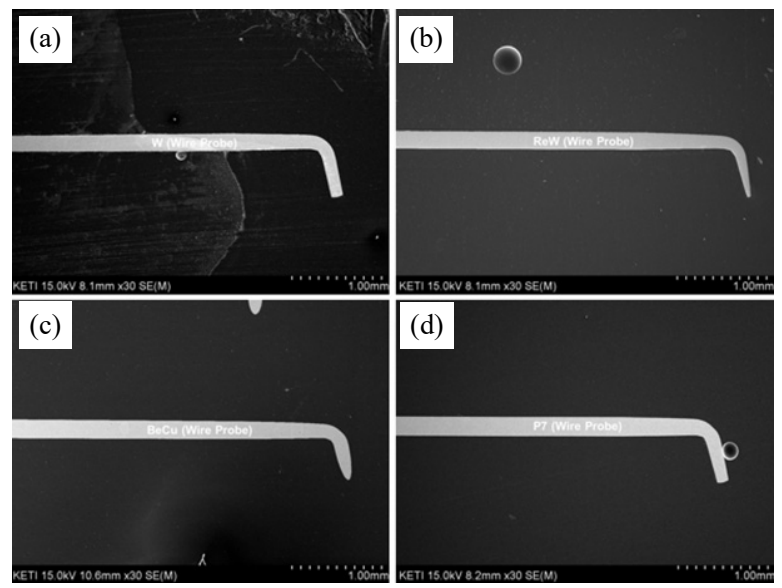

Fig. 1 SEM micrographs of cantilever wire probes, (a) W, (b) $\mathrm{ReW}$, (c) BeCu and (d) P7

Table 1 Chemical composition and materials properties of cantilever wire probes

\begin{tabular}{|c|c|c|c|c|}
\hline Cantilever wires & Alloy composition & $\begin{array}{c}\text { Melting temperature } \\
\left({ }^{\circ} \mathrm{C}\right)\end{array}$ & $\begin{array}{c}\text { Density } \\
\left(\mathrm{g} / \mathrm{cm}^{3}\right)\end{array}$ & $\begin{array}{c}\text { Electrical resistivity } \\
\left(\mu \Omega \cdot \mathrm{cm}, 20^{\circ} \mathrm{C}\right)\end{array}$ \\
\hline $\mathrm{W}$ & $100 \%$ Tungsten & 3,410 & 19.24 & $5.59-5.86$ \\
\hline $\mathrm{ReW}$ & Rhenium-tungsten & 3,410 & 19.29 & $9.15-9.65$ \\
\hline $\mathrm{BeCu}$ & Beryllium copper & 925 & 8.4 & 7.0 \\
\hline $\mathrm{P7}$ & Palladium-silver-coper & 1,066 & 11.8 & 31.6 \\
\hline
\end{tabular}




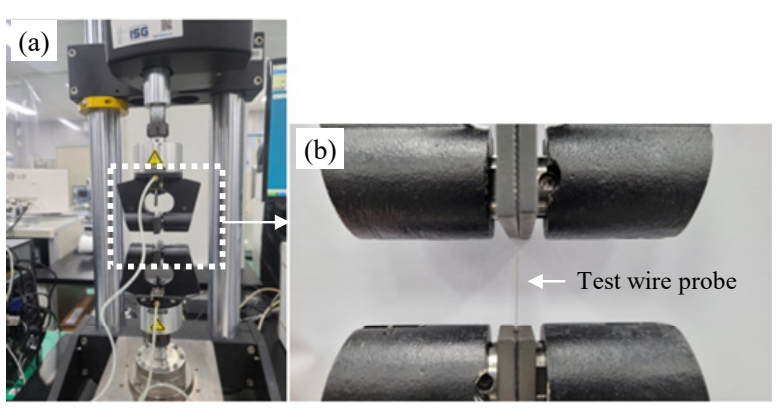

Fig. 2 Photographs of (a) tensile test and (b) magnified images of wire probe

\subsection{Scrub mark analysis and touch-down fatigue test}

The size of the scrub marks generated on the chip surfaces were measured after one $\mathrm{T} / \mathrm{D}$ to analyze the scrub marks generated during the power semiconductor element measurement with wire probes. The chip used in the experiment was a 9x9 mm diode (Trinno Technology Co. Ltd., South Korea) element used in power semiconductors, in which the chip surface was coated with a $4 \mu \mathrm{m}$ aluminum (Al) thin-film. The scrub mark test proceeded with the application of a compressive load when the wire probe tip moved $-80 \mu \mathrm{m}$ from point of the contact on the chip surface, followed by the comparison of the sizes and lengths of the scrub marks generated on the diode surface.

Instron 8848 was used in the T/D fatigue test, similar to the scrub mark test, in which 100,000 test cycles proceeded as shown in Fig. 3, with the conditions shown in Table 2. During the T/D test, the test was set to be suspended at a $30 \%$ reduction in the fatigue load, con-

Table 2 Fatigue test condition for T/D test of cantilever wire probe

\begin{tabular}{|c|c|c|c|c|}
\hline Amplitude $(\mu \mathrm{m})$ & Mean level $(\mu \mathrm{m})$ & Frequency $(\mathrm{Hz})$ & Wave form & Test cycles $($ cycles $)$ \\
\hline 50 & -30 & 5 & Sine Wave & 100,000 \\
\hline
\end{tabular}
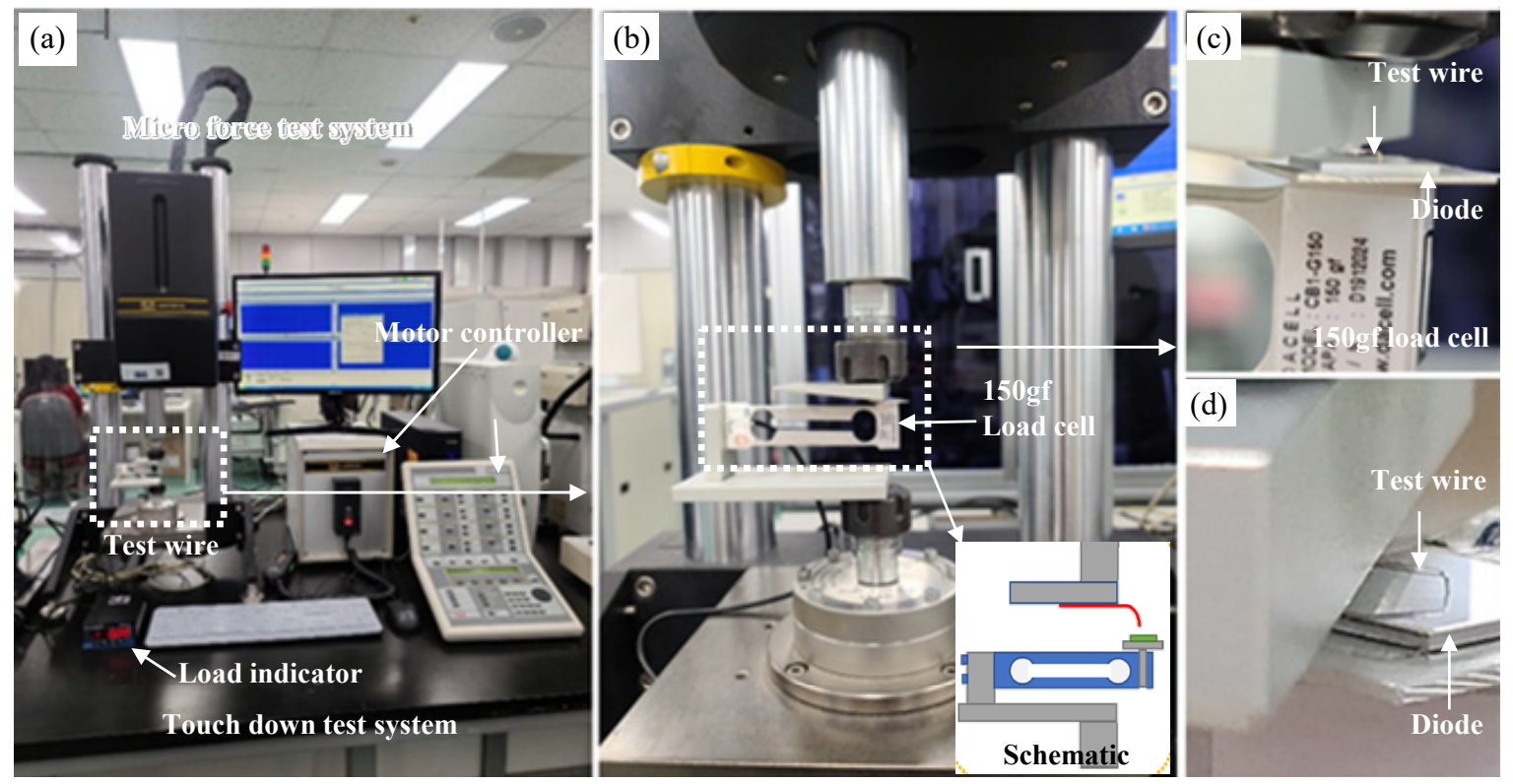

(e)
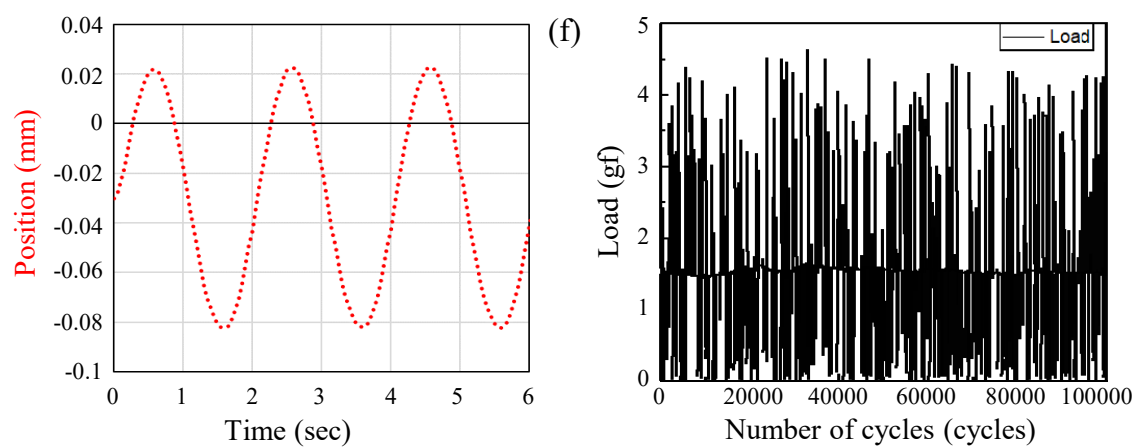

Fig. 3 Photographs of T/D test set-up using by micro fatigue test system, (a) test system, (b) magnified view of fixed wire and load cell and (c,d) enlarged images of cantilever wire 
sidering the fracture generation in the wire probe. In addition, the wire was set to be $3.8 \mathrm{~mm}$ protruded from the wire fixing jig and fixed at a $7^{\circ}$ tilt, similar to the wire probe installed in an actual probe card, to proceed with 100,000 fatigue tests. The T/D fatigue test proceeded based on the displacement control. Here, loads of $-10.5,9.7,5.35$, and 7.4 gf were applied on W, ReW, $\mathrm{BeCu}$, and $\mathrm{P} 7$ cantilever wire probes, respectively, with the $-80 \mu \mathrm{m}$ movement to the direction of compression. Since the range of compressive load is small, the load cell (CB1-G150, Dacell Co, Ltd., South Korea) with the maximum load range of $150 \mathrm{gf}$ was used. The diode used in the T/D was fixed on the $150 \mathrm{gf}$ load cell, and the fatigue test was set for the wire probe to repetitively touch down the diode surface. Here, the position of the repetitive motion of the device and the compressive load applied were monitored in real-time during the fatigue test. In the inspection with an actual probe card, the probe card movement inspects the power semiconductor wafer based on the $-80 \mu \mathrm{m}$ displacement rather than the load, so the fatigue test this experiment proceeded with a $-80 \mu \mathrm{m}$ displacement control as well. The $-40 \mu \mathrm{m}$ was set to the mean level to repetitively move the wire probe to its $-80 \mu \mathrm{m}$ objective, and the wire probe can repetitively move $-80 \mu \mathrm{m}$ when $\pm 40 \mu \mathrm{m}$ is repetitively traveled back and forth. However, in this case, a non-contact condition between the wire probe and diode surface is not achieved, for which the test conditions were set to enable $\pm 50 \mu \mathrm{m}$ movement based on $-30 \mu \mathrm{m}$, as shown in Fig. 3(e). The repetitive T/D frequency of the probe was set to $5 \mathrm{~Hz}$.

\subsection{SEM and EBSD analysis}

Before and after the T/D fatigue test, a cross-section of the wire probe and the angle of the bending part of the tip were measured. During the 100,000 cycles of fatigue tests, the SEM and EBSD analyses were performed to observe the bending part angle and the microstructural variations for each wire probe material. In particular, to observe the strain generated from the bending part microstructure and the grain orientation variations, the inverse pole figure (IPF), grain reference orientation deviation (GROD) maps, and the strain contouring maps were measured for comparative analysis.

\section{Experimental results}

\subsection{Cantilever wire probe tensile strength measure- ment results}

The tensile strength measurement results for the four types of wire probes are shown in Fig. 4. They were

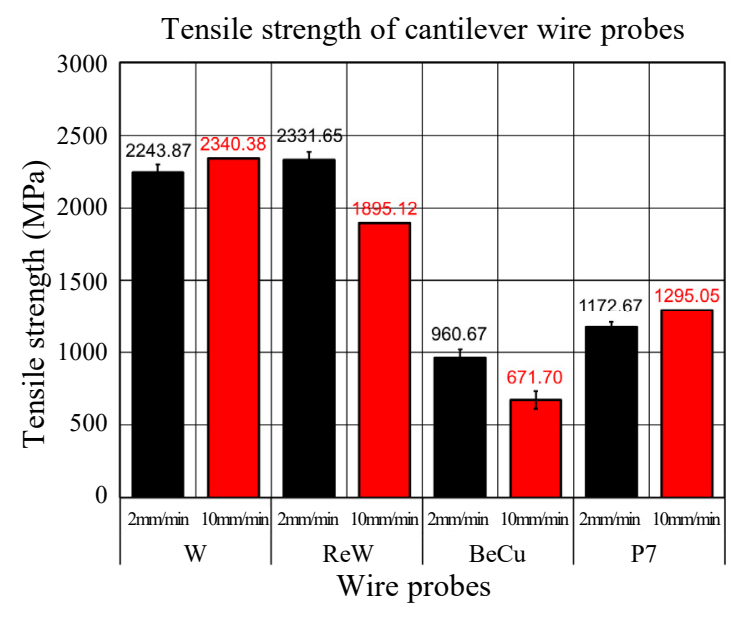

Fig. 4 Tensile strength of 4 kinds of cantilever wire probes with test speed
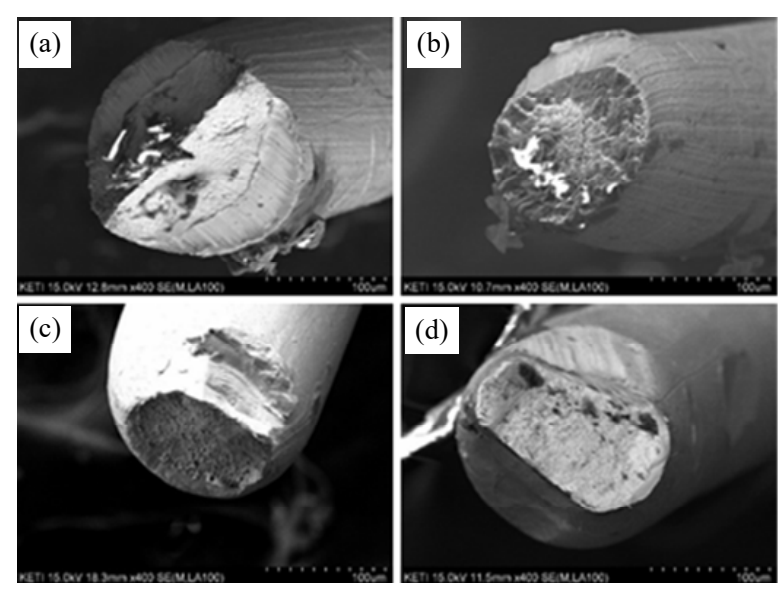

Fig. 5 Fracture surface SEM images of cantilever wire probes after tensile test, (a) W, (b) $\mathrm{ReW}$, (c) $\mathrm{BeCu}$ and (d) P7

2.2-2.3, 1.9-2.3, 0.67-0.96, and 1.2-1.3 GPa for W, ReW, $\mathrm{BeCu}$, and $\mathrm{P} 7$, respectively. The tensile strengths of $\mathrm{W}$ and ReW wires were measured to be higher than the wires containing $\mathrm{Cu}$ or $\mathrm{Ag}$, while the toughness and elongation rate were measured to be higher in the $\mathrm{BeCu}$ and $\mathrm{P} 7$ wires. As shown in Fig. 5, it can be seen that W and ReW showed brittle fractures and a mixture of ductile and brittle fracture modes, $\mathrm{BeCu}$ formed a ductile fracture plane, and brittle fractures were generated more in the P7. Thus, for the probe card, it is considered critical to select a wire probe material that has suitable fatigue strength and fatigue cycles from the repetitive T/D assessment.

\subsection{Scrub mark analysis results}

The scrub mark sizes according to the wire probes were measured as $12.5,25.6,32.3$, and $61.7 \mu \mathrm{m}$ in $\mathrm{W}$, 

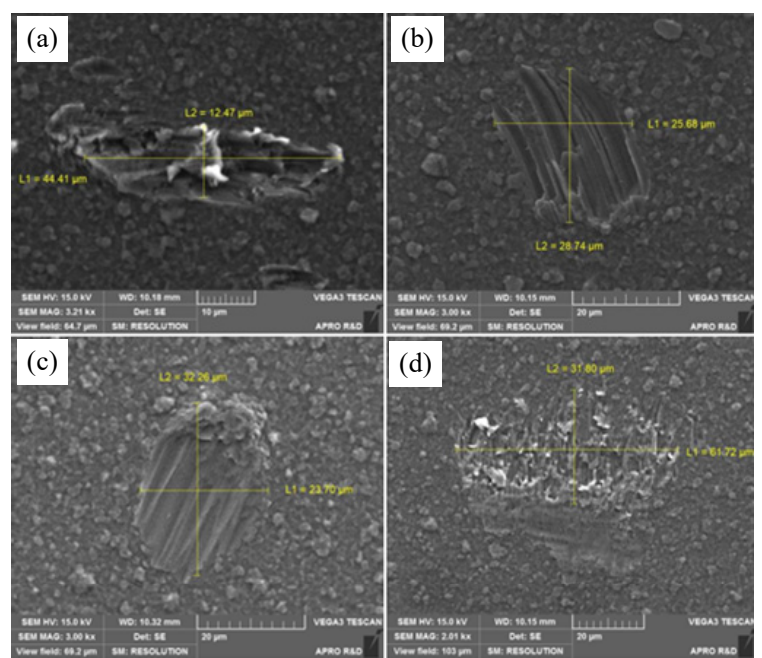

Fig. 6 SEM micrographs of scrub mark generated on the diode surface after 1 cycle T/D test, (a) W, (b) $\mathrm{ReW}$, (c) BeCu and (d) P7

$\mathrm{ReW}, \mathrm{BeCu}$, and $\mathrm{P} 7$, respectively. The $\mathrm{W}$ or $\mathrm{ReW}$, which had high tensile strength measurements and aspects of brittle fractures from above, caused minimum scrub marks on the diode surface. In contrast, wire materials containing $\mathrm{Cu}$ had longer scrub marks and more contamination at the diode surface. Thus, $\mathrm{W}$ or ReW materials were considered to be beneficial for repressing the generation of scrub marks.

\subsection{Cantilever wire microstructures after touch-down fatigue test}

The measurement results of the bending angle of the wire bending part after the $100,000 \mathrm{~T} / \mathrm{D}$ test that implements $-80 \mu \mathrm{m}$ displacement of the cantilever wire are shown in Fig. 7. The measurements were $102^{\circ}, 103$ $104^{\circ}, 102^{\circ}$, and $100-102^{\circ}$ in the $\mathrm{W}, \mathrm{ReW}, \mathrm{BeCu}$, and $\mathrm{P} 7$

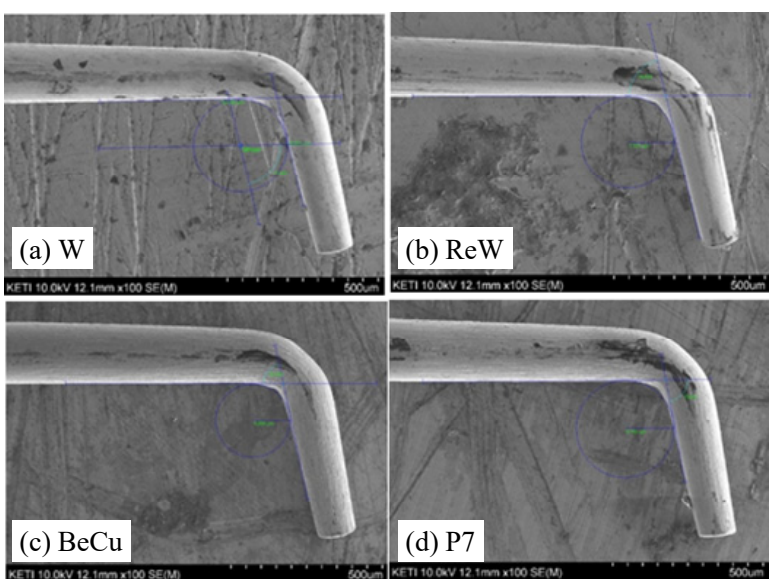

Fig. 7 SME images of cantilever wire probes after 100,000 cycles T/D fatigue test, (a) W, (b) ReW, (c) $\mathrm{BeCu}$ and (d) P7

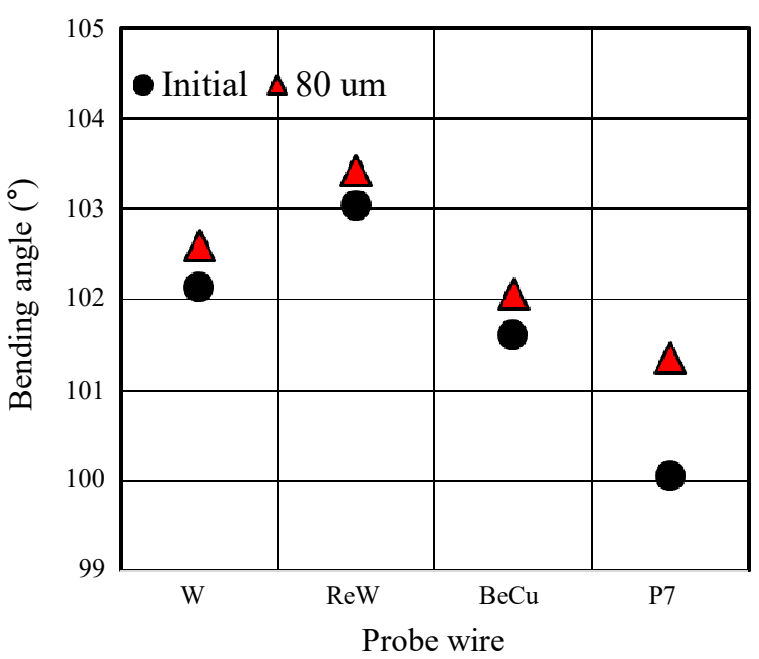

Fig. 8 Bending angle comparison of cantilever wire probes before and after 100,000 cycles T/D fatigue test

wires, respectively. Thereby, the P7 material showed the most wire deformation after the T/D fatigue test, followed by the $\mathrm{BeCu}$ wire. In comparison to the tensile strength assessment results, $\mathrm{BeCu}$ and $\mathrm{P} 7$ wires that have high elongation rates and tensile strengths showed larger deformations at the wire bending parts.

The SEM image and EBSD analyses results of the wire probe bending parts after the $100,000 \mathrm{~T} / \mathrm{D}$ fatigue tests are shown in Fig. 9. The variations of the deformed microstructures due to the repetitive tensile stress on the wire bending parts were comparatively analyzed using IPF images, GROD maps, and Strain contouring maps. Through IPF scanning images, the misorientation areas can be observed for the grain orientation, and the grain refinement or deformed areas can be distinguished. In the EBSD strain contouring map, plastic deformation can be located based on the localized misorientation areas, and the generation of the largest local plastic deformation can be located. In addition, through the EBSD GROD scanning, the residual stress area can be distinguished, and the relationship between the grain misorientation angle and the average grain orientation axis for all grains can be identified. The deformed microstructures in the wire probe bending parts were qualitatively compared through EBSD scanning analysis, which is shown in Fig. 9. Fig. 9(a) and (d-k) are the SEM and EBSD analyses results before and after the 100,000 T/D tests on the $\mathrm{W}$ wire probe, Fig. 9(b) and (i-s) on the ReW wire probe, and Fig. 9 (c) and (t-a $\alpha)$ on the P7 wire probe. From the results of each specimen, it was identified that the grain at the bending part was elongated after the tests. This was identified to stem from the stress applied to the 

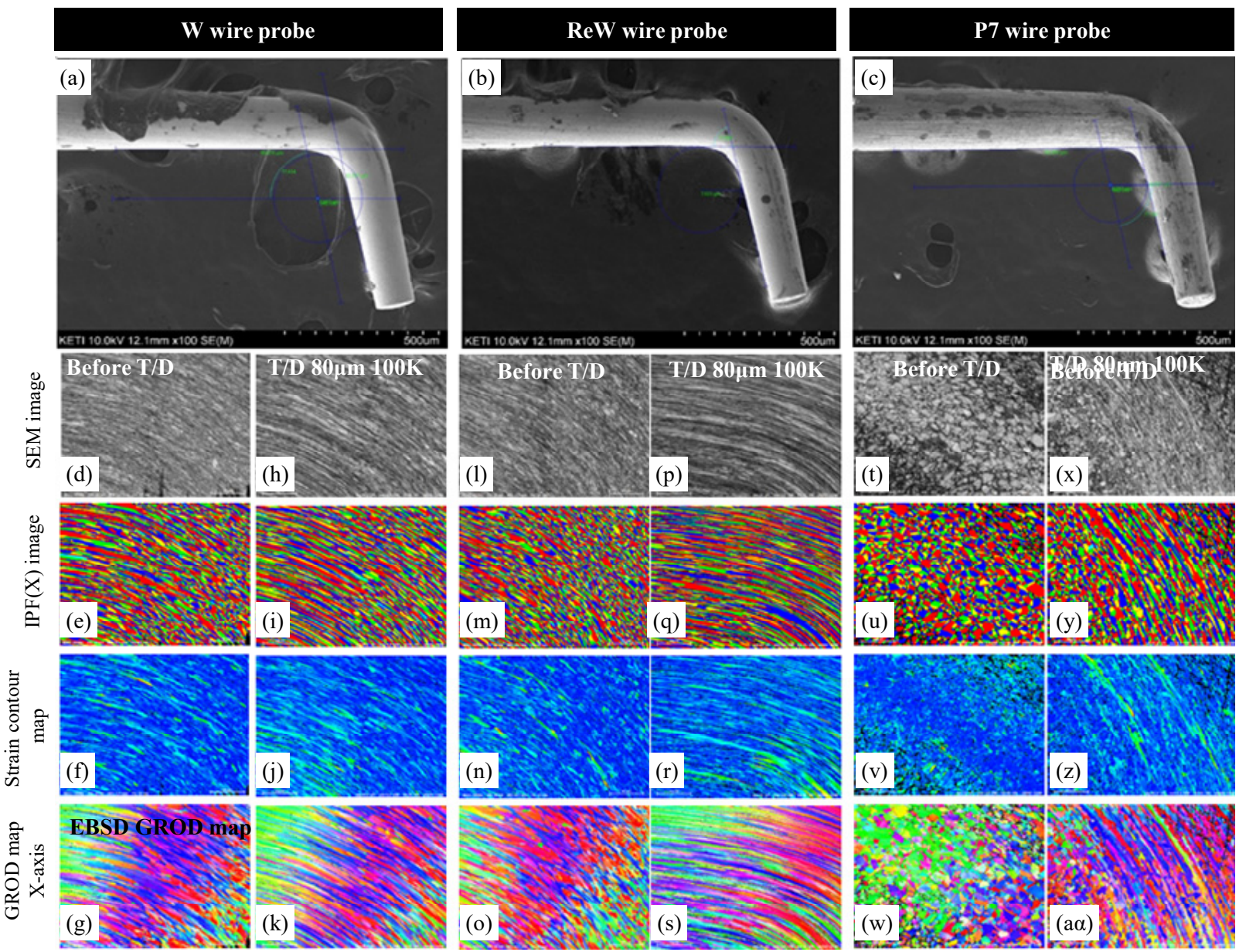

Fig. 9 SEM images and EBSD analysis results of bending area of cantilever wire probes after 100,000 cycles T/D fatigue test, (a) and (d-k) W, (b) and (i-s) ReW, and (c) and (t-a $\alpha$ ) P7

bending part during the repetitive T/D tests and to have elongated the bending part in the $\mathrm{x}$-axis length direction. Additionally, the strain contouring map analysis results showed that there were more misorientation grains at the bending part. In the case of the $\mathrm{W}$ wire, the grain was longer than other wire microstructures before the tests but expanded even longer after the T/D tests. The fatigue resistance to such grain elongations or the resistance to fatigue stress is manifested as higher in materials with greater fracture toughness than tensile strength. Therefore, W and ReW with fundamentally high yield strengths are considered to have small deformations due to misorientations and strain generations from grain elongations, while materials with low yield strengths exhibit greater strain generations due to grain orientation deformations ${ }^{3-8)}$. Consequently, rather than those with high initial yield strengths, those with small deformations of the wire probe after long hours of use, namely $\mathrm{ReW}, \mathrm{W}$, and $\mathrm{BeCu}$ materials were considered to have superior touch-down fatigue characteristics to the P7 material.

\section{Conclusions}

This study measured the tensile strengths and the scrub mark properties of the four types of cantilever wire probes that either used $\mathrm{W}, \mathrm{ReW}, \mathrm{BeCu}$, or P7 alloys. Additionally, the fatigue characteristics of the wire and the variations in the microstructures according to the T/D fatigue tests were qualitatively and comparatively analyzed through SEM and EBSD scanning, which resulted as follows.

1) The wire probe tensile strength measurement results showed that they were high in $\mathrm{W}$ and ReW materials, and while the tensile strengths decreased in wires containing $\mathrm{Cu}$ or $\mathrm{Ag}$, the toughness and elongation rates had increased. In $\mathrm{W}$ and ReW materials, brittle fractures and a mixture of ductile and brittle fracture modes were shown, $\mathrm{BeCu}$ formed a plane of ductile fracture, and more brittle fractures were generated in P7.

2) The results of measuring the bending angle of the cantilever wire bending parts after 100,000 T/D tests showed that the greatest deformation was in $\mathrm{P} 7$, followed by $\mathrm{BeCu}$. In comparison to the yield strength re- 
sults, bending part deformations were greater in $\mathrm{BeCu}$ and $\mathrm{P} 7$ materials that had high elongation rates and low tensile strengths.

3) In the $W$ and ReW wire probes that had high initial yield strengths, the misorientation angle deformations due to the grain elongation were smaller than that in the P7 wire probe. Thereby, their grain deformations due to the generation of strains were lower, while materials with low initial yield strengths had larger strain generations due to the deformation of grain orientation. Therefore, long-term conditions of T/D use were considered to be superior in $\mathrm{ReW}, \mathrm{W}$, and $\mathrm{BeCu}$ than in $\mathrm{P} 7$, because deformations were small after a long period of use rather than having high initial tensile strengths.

\section{Acknowledgements}

This research was conducted with the funding from the Material and Components Technology Development Project (Project number: 20009828) supported by the Ministry of Trade, Industry and Energy.

ORCID: Won Sik Hong: http://orcid.org/0000-0001-8398-177X ORCID: Mi-Song Kim: https://orcid.org/0000-0002-4717-9365 ORCID: Myeongin Kim: https://orcid.org/0000-0002-5151-1404

\section{References}

1. Korea Institute of Science and Technology Information (KISTI), Technical Tren of Semi-conductor Measurement and Inspection Equipment, The Ministry of Trade, Industry and Energy (MOTIE) and Materials \& Component Technology Network (MCT-Net), Accessed on https:// www.mctnet.org (2020).
2. W. S. Hong, M. S. Kim, M. Kim, S. H. Yun, and Y. Park, Laser Soldering Properties of MEMS Probe for Semiconductor Water Testing, J. Weld. Join. 39(4) (2021) 368-375. https://doi.org/10.5781/JWJ.2021.39.4.4

3. A. Palaniappan, L. Li, and T.-K. Lee, Impact of Pressfit Connector Pin Microstructure Elastic Response to PCB Through-hole $\mathrm{Cu}$ Wall Interface Long-term Contact Reliability, Proc. 2018 IEEE 20th Electron. Packag. Techol. Conf. EPTC 2018, 890 (2018). https://doi.org/10.1109/EPTC.2018.8654324

4. Y. J. Baek, A. Palaniappan, G. Baty, L. Li, S. K. Hyun, and T. K. Lee, Impact of Thermal Cycling on Cu PressFit Connector Pin Interconnect Mechanical Stability, $J$. Electron. Mater. 50(11) (2021) 4991-4998.

5. L.N. Brewer, D.P. Field, and C.C. Merriman, Mapping and Assessing Plastic Deformation Using EBSD, Electron Backscatter Diffraction in Materials Science., ed. A.J. Schwartz, M. Kumar, B.L. Adams, and D.P. Field (US, Boston, MA: Springer, 2009) 251-262. https://doi.org/10.1007/s11664-021-09045-w

6. S. Kim, W. S. Hong, H. Nam, and N. H. Kang, Growth Behavior of Intermetallic Compounds in Various Solder Joints Induced by Electromigration, J. Weld. Join. 39(1) (2021) 89-102. https://doi.org/10.5781/JWJ.2021.39.1.11

7. W. S. Hong and C. Oh, PoF Based Accelerated Life Prediction with 3 Dimensional Packaging Technology Development, J. Korean Weld. Join. Soc. 27(3) (2009) 10-16.

8. W. S. Hong and C. M. Oh, Thermal Shock Reliability of Low Ag Composition Sn-0.3Ag-0.7Cu and Near Eutectic Sn-3.0Ag-0.5Cu Pb-free Solder Joints, J. Korean Inst. Met. Mater. 47(12) (2009) 842-851. 


\title{
전력반도체 웨이퍼 검사용 컨틸레버 와이어 프로브의 피로 주기에 따른 미세조직 변화
}

\section{Microstructure Evolution of Cantilever Wire Probe after Touch-Down Fatigue Cycles for Power Semi-conductor Wafer Testing}

\author{
홍 원 식*·김 미 송* ·김 명 인* \\ *한국전자기술연구원 융복합전자소재연구센터
}

\section{1. 서 론}

최근 실리콘 카바이드 (Silicon Carbide, $\mathrm{SiC}$ ) 및 질화갈륨 (Gallium Nitride, GaN) 소재 기반의 화합 물 반도체 (Wide band gap, WBG)가 상용화가 되고 있으며, 이 화합물 반도체를 이용한 고효율, 고주파수, 고신뢰성 및 고전력 밀도의 전력변환 시스템 (인버터 및 컨버터 등 파워모듈 (Power module))의 개발이 본격화됨에 따라 WBG 기반의 Power module에 대한 수요가 점차 증가하고 있다. 친환경 전기자동차는 기존 내연기관에 비하여 전기에너지 사용량이 크게 증대되기 때문에 전력변환에 대한 고효율화가 중요하다. 직류와 교 류의 전력변환을 전력반도체 (Power semiconductor) 스위칭 특성을 이용하여 원하는 위상과 주파수로 출력 변환시키는 인버터 및 컨버터와 같은 전력변환 시스템 이 매우 중요하게 되었다. 수송기기용 파워모듈은 대전 력의 $\mathrm{Si}$ 또는 $\mathrm{SiC}$ 전력반도체를 사용하기 때문에 이러 한 전력반도체 수요는 최근 들어 급속히 증가하고 있 다. 이에 따라 대전력의 전력반도체 소자를 생산하기 위한 전력반도체용 프로브 카드 개발도 동시에 진행되 고 있다.

프로브 카드 (Probe card)는 반도체 공정 중 완성 된 웨이퍼 (Wafer) 내 개별 칩 (Chip)의 전기적 동작 여부를 검사하기 위한 검사공정에 사용되는 신호전달 매개체로 사용된다. 프로브 카드는 테스트 (Test) 하 는 반도체 소자의 사양에 맞게 개별적으로 설계, 제조 하여 주문 제작되는 제품이다. 생산되는 반도체 소자의 사양이 변경될 때마다 그에 따른 프로브 카드가 새로 제 작되어야 하므로 고부가가치 제품으로 분류된다. 또한 프 로브 카드는 반도체 제조공정 중 전 공정 (Fabrication) 이 완료된 상태에서 Test를 위한 핵심부품 중 하나이
다 $^{1,2)}$. 프로브 카드 형태로는 웨이퍼 내 칩의 전기적 동작 상태를 검사하기 위해 아주 미세한 선 형태의 접 촉 핀 (Pin) (또는 프로브)을 일정한 규격의 인쇄회로 기판 (Printed circuit board, $\mathrm{PCB}$ ) 등에 부착한 카 드로, 이 프로브가 웨이퍼에 접촉되면서 웨이퍼와 측정 장비의 중간 매개체 역할을 함으로써 반도체 칩의 양품 과 불량을 전수 검사하게 된다. Wire를 이용한 컨틸레 버 와이어 (cantilever wire) 프로브 카드는 프로브의 치수가 길고 모든 프로브의 전장을 균등하게 갖추기가 곤란하기 때문에 고속신호의 전송에는 한계가 발생하지 만, 전력반도체 소자와 같이 고전압 대전류를 사용하는 반도체 소자의 검사에 적합한 방식이다. 그러나 프로브 카드를 웨이퍼 검사에 반복적으로 수 만회 이상을 사용 하기 때문에, 전력반도체 Wafer 표면의 측정단자 $(\mathrm{In} /$ Out, I/O)를 Wire가 접촉하여 측정하기 때문에, 프로 프브 카드에 사용되는 와이어에는 반복 피로 (Fatigue) 하중이 지속적으로 인가되는 문제가 있다. 이에 따라 프로브 카드의 와이어 굽힙부에 피로 하중에 의한 피로 파괴 (Fracture) 가 발생되기 때문에, 와이어의 소재 에 따른 피로특성이 향상된 와이어 소재 개발이 요구되 고 있다. 또한 프로브 카드의 Wire가 웨이퍼 표면의 $\mathrm{I} / \mathrm{O}$ 측정시 터치다운 (Touch-down, T/D) 방식으로 접촉되기 때문에 웨이퍼 윗면의 Chip 표면에 스크럽 (Scrub) 발생의 문제를 야기한다. 따라서 와이어 프로 브 소재는 굽힘강도와 피로강도가 우수하여야 하며 동 시에 Scrub mark를 유발하지 않는 소재 개발이 요구 되고 있다.

따라서 본 연구에서는 4종의 텡스텐 (Tungsten, W), 레늄-텡스텐 (Rhenium-Tungsten, ReW), 베릴륨구 리 (Beryllium-Copper, $\mathrm{BeCu}$ ) 그리고 P7 (PalladiumSilver-Copper alloy, $\mathrm{Pd}-\mathrm{Ag}-\mathrm{Cu}$ ) 합금을 이용하여 프 로브 카드에 사용되는 전력반도체 웨이퍼 측정용 canti- 
lever wire의 인장강도 특성을 측정하고, T/D Fatigue 시험에 따른 Wire의 피로특성 및 미세조직 변화를 주사 전자현미경과 (Scanning electron microscopy, SEM) 과 전자후방산란회절 (Electron back-scattered diffraction, EBSD) 분석을 통해 비교분석하였다.

\section{2. 실험 방법}

\section{1 컨틸레버 프로브 와이어 소재}

본 연구에 사용된 4종 Cantilever wire probe에 대한 원소재 합금종류 및 재료물성 값은 다음 Table 1 에 나타내었다. 융점과 인장강도가 높은 $\mathrm{W}$ 과 $\mathrm{ReW}$ 원 소 대비 인장강도가 낮은 $\mathrm{BeCu}$ 와 $\mathrm{Pd}-\mathrm{Ag}-\mathrm{Cu}$ 합금소 재을 사용하였다. Wire probe의 SEM 사진은 Fig. 1에 나타냈으며, 4종 Wire probe tip 직경은 $\mathrm{W}, \mathrm{ReW}$, $\mathrm{BeCu}$ 그리고 $\mathrm{P} 7$ 이 각각 $118,43,69$ 그리고 $118 \mu \mathrm{m}$ 였다.

\subsection{Cantilever Wire 인장강도 측정}

4종 Wire probe에 대한 인장강도는 Fig. 2와 같이 Instron 8848 (8848, Instron Co. Ltd., USA) 장 비를 사용하여 측정하였다. Seratted jaw face를 갖
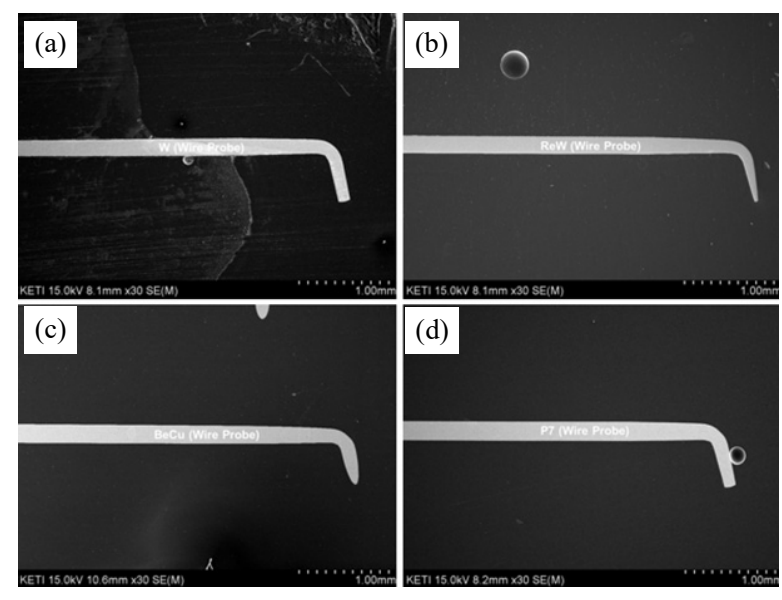

Fig. 1 SEM micrographs of cantilever wire probes, (a) W, (b) ReW, (c) BeCu and (d) P7

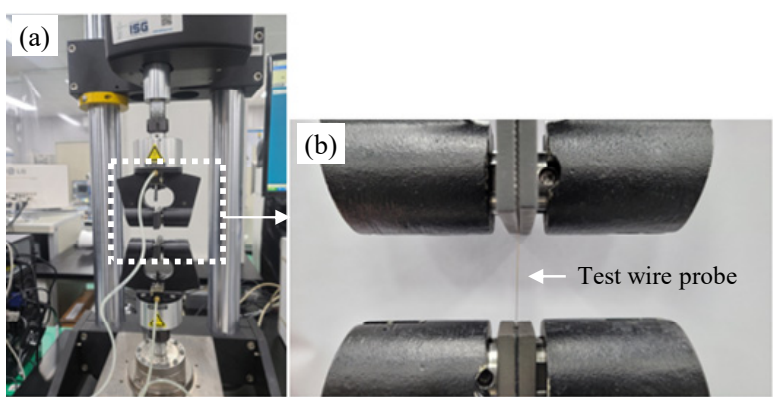

Fig. 2 Photographs of (a) tensile test and (b) magnified images of wire probe

는 인장시험용 Grip을 이용하여 고정한 후 2 와 10 $\mathrm{mm} / \mathrm{min}$ 속도로 인장강도를 측정하였으며, 시험속도 에 대한 영향도를 비교하였다.

\subsection{Scrub Mark 분석 및 Touch-Down 피로시험}

Wire Probe에 대한 전력반도체 소자의 측정 중 발 생되는 Scrub mark 분석을 위해 1회 T/D 후 Chip 표면에 생성된 Scrup mark 크기를 측정하였다. 시험에 사용된 Chip은 $9 \times 9 \mathrm{~mm}$ 크기의 전력반도체용 다이오드 (Diode, Trinno Technology Co. Ltd., Korea) 소 자로써, Chip 표면은 $4 \mu \mathrm{m}$ 두께의 알루미늄 (Al) 박막 코팅이 되어 있었다. Scrup mark 시험은 Wire probe tip이 Chip 표면에 접촉한 시점으로부터 $-80 \mu \mathrm{m}$ 이동시 압축하중으로 가압한 후 다이오드 표면에 생성된 Scrub mark의 크기와 길이를 분석하였다.

$\mathrm{T} / \mathrm{D}$ 피로시험은 Scrub mark 시험과 동일한 방법 으로 Instron 8848 장비를 이용하여 100,000회 반 복 피로시험을 Table 2 의 조건으로 Fig. 3에서와 같 이 진행하였다. T/D 시험중 Wire probe의 Fracture 발생을 고려하여 시험이 진행되는 피로하중의 $30 \%$ 하 중 감소가 발생되면 시험을 중단하도록 설정하였다. 또 한 실제 프로브 카드에 설치되는 Wire probe와 동일 하도록 와이어 고정 지그로부터 와이어는 $3.8 \mathrm{~mm}$ 돌 출되어 $7^{\circ}$ 기울여진 상태로 고정된 후 10 만 회 피로시험 을 진행하였다. T/D 피로시험은 변위 컨트롤 (Displacement control) 기준으로 진행하였다. 이때 $-80 \mu \mathrm{m}$ 압

Table 1 Chemical composition and materials properties of cantilever wire probes

\begin{tabular}{|c|c|c|c|c|}
\hline Cantilever wires & Alloy composition & $\begin{array}{c}\text { Melting temperature } \\
\left({ }^{\circ} \mathrm{C}\right)\end{array}$ & $\begin{array}{c}\text { Density } \\
\left(\mathrm{g} / \mathrm{cm}^{3}\right)\end{array}$ & $\begin{array}{c}\text { Electrical resistivity } \\
\left(\mu \Omega \cdot \mathrm{cm}, 20^{\circ} \mathrm{C}\right)\end{array}$ \\
\hline $\mathrm{W}$ & $100 \%$ Tungsten & 3,410 & 19.24 & $5.59-5.86$ \\
\hline $\mathrm{ReW}$ & Rhenium-tungsten & 3,410 & 19.29 & $9.15-9.65$ \\
\hline $\mathrm{BeCu}$ & Beryllium copper & 925 & 8.4 & 7.0 \\
\hline $\mathrm{P7}$ & Palladium-silver-coper & 1,066 & 11.8 & 31.6 \\
\hline
\end{tabular}

본 논문은 독자의 이해를 돕기위하여 영문논문을 국문으로 번역하여 게재한 논문입니다. 저자는 본 논문으로 연구업적과 같은 실적에 중복으로 지원받거나 인정받을 수 없음을 알려드립니다. 
Table 2 Fatigue test condition for T/D test of cantilever wire probe

\begin{tabular}{|c|c|c|c|c|}
\hline Amplitude $(\mu \mathrm{m})$ & Mean level $(\mu \mathrm{m})$ & Frequency $(\mathrm{Hz})$ & Wave form & Test cycles $($ cycles $)$ \\
\hline 50 & -30 & 5 & Sine Wave & 100,000 \\
\hline
\end{tabular}
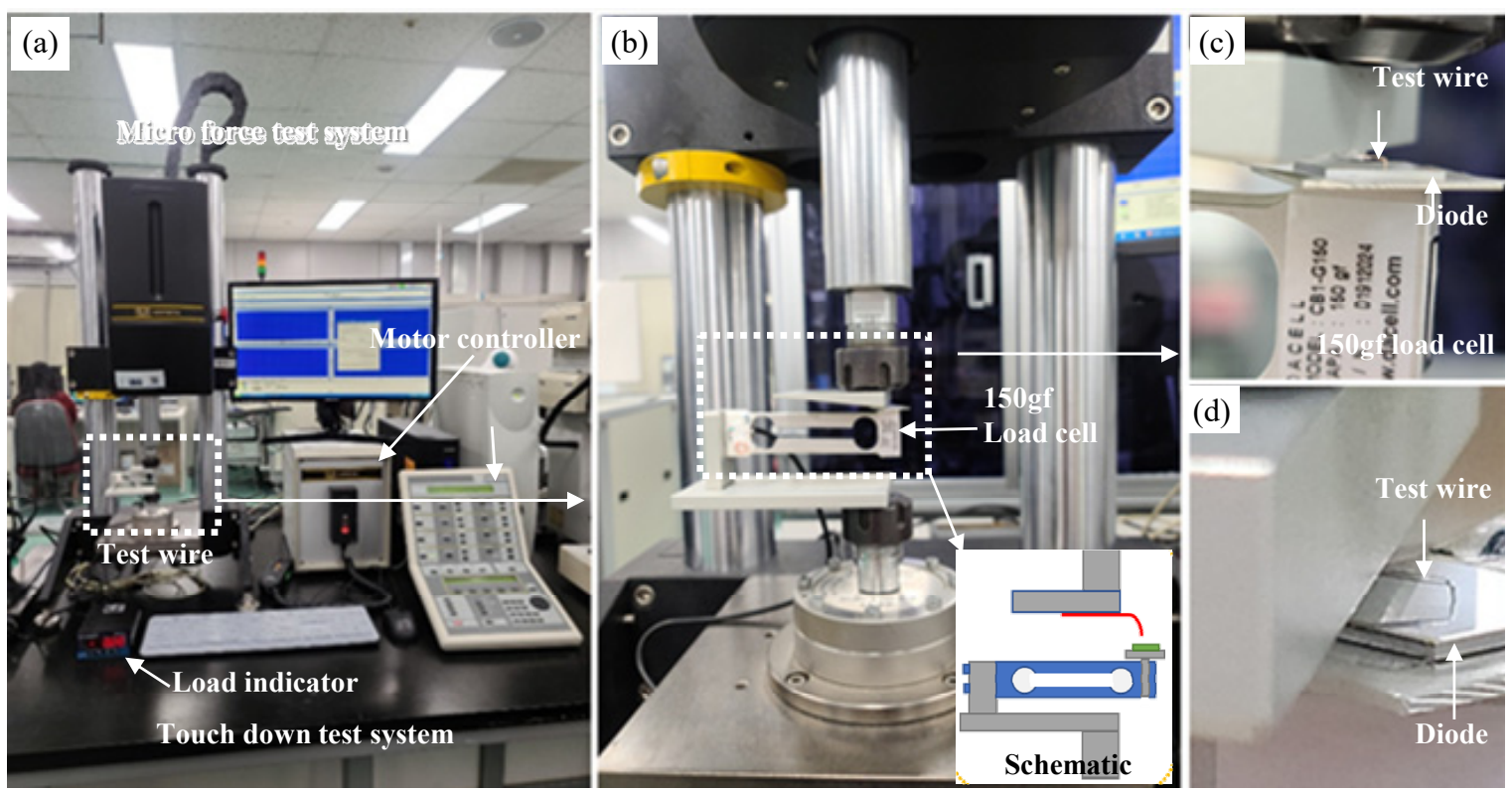

(e)
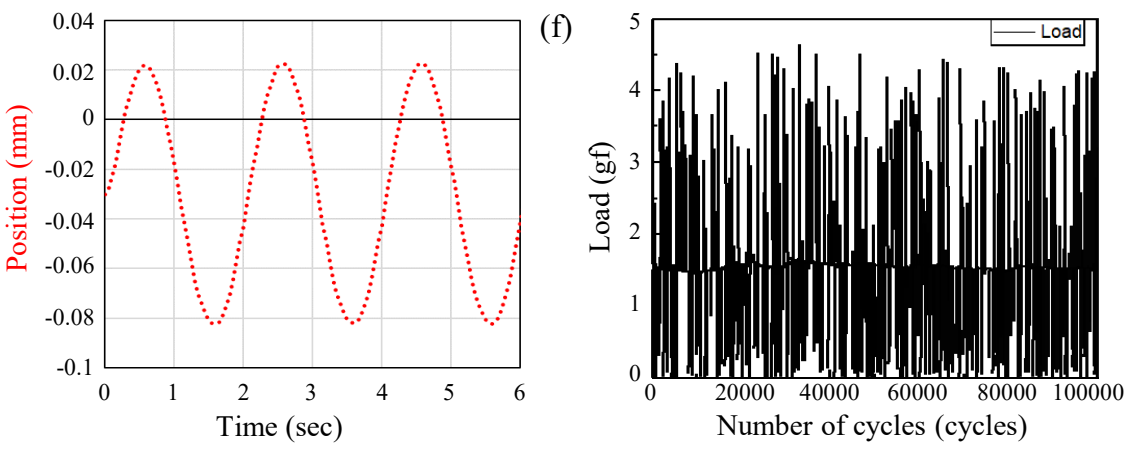

Fig. 3 Photographs of T/D test set-up using by micro fatigue test system, (a) Test system, (b) magnified view of fixed wire and load cell and (c,d) enlarged images of cantilever wire

축방향 이동시 4종의 $\mathrm{W}, \mathrm{ReW}, \mathrm{BeCu}$ 그리고 $\mathrm{P} 7 \mathrm{Can}-$ tilever wire probe에 가해지는 하중은 각각 -10.5 , $9.7,5.35$ 그리고 $7.4 \mathrm{gf}$ 로 인가되었다. 압축하중의 범위가 매우 작기 때문에, 최대 하중범위 $150 \mathrm{gf}$ 를 갖 는 로드 셀 (CB1-G150, Dacell Co, Ltd., Korea) 을 사용하였다. T/D에 사용된 Diode는 $150 \mathrm{gf} \mathrm{Load}$ cell 위에 고정한 후, Wire probe가 Diode 표면을 반 복적으로 Tocu-down 하도록 피로시험을 설정하였다. 이때 장비가 반복 거동하는 Position과 가해지는 압축 하중은 실시간으로 장비에서 모니터링 하며 피로시험이 진행되었다. 실제 프로브 카드로 검사할 경우, 프로브 카드의 이동은 하중 중심이 아니라 $-80 \mu \mathrm{m}$ 변위 중심으 로 전력반도체 웨이퍼를 검사하기 때문에, 본 실험에서 도 $-80 \mu \mathrm{m}$ Displacement control 피로 시험을 진행하
였다. 와이이 프로브가 $-80 \mu \mathrm{m}$ 를 반복 이동하게 하기 위 해서는 $-40 \mu \mathrm{m}$ 를 Mean level로 설정하고 $\pm 40 \mu \mathrm{m}$ 를 반복 왕복할 경우, Wire probe는 목표하는 $-80 \mu \mathrm{m}$ 반복 거동이 가능하게 된다. 그러나 이 경우, Wire probe가 Diode의 표면으로부터 비접촉이 발생하지 않기 때문에, 시험조건 설정시에는 Fig. 3(e)에서와 같이 $-30 \mu \mathrm{m}$ 를 기준으로 $\pm 50 \mu \mathrm{m}$ 를 이동할 수 있도록 실험조건을 설정 하여 진행하였다. 프로브가 $\mathrm{T} / \mathrm{D}$ 을 반복하는 주파수는 $5 \mathrm{~Hz}$ 로 진행하였다.

\subsection{SEM 및 EBSD 분석}

$\mathrm{T} / \mathrm{D}$ 피로시험 전후 Wire probe에 대한 단면분석 및 Tip의 Bending 부에 대한 각도를 측정하였다. 10 
만 회 피로시험 중 Wire probe의 소재별 Bending 부 각도 변화 및 미세조직의 변화 관찰을 위해 $\mathrm{SEM}$ 과 $\mathrm{EBSD}$ 분석을 진행하였다. 특히 Bending 부 미세조 직에서 발생된 Strain과 입자 방향성 (Grain orientation) 변화를 관찰하기 위해, Inverse pole figure (IPF)와 Grain reference orientation deviation (GROD) maps 그리고 Strain contouring maps을 측정하여 비교분석 하였다.

\section{3. 실험 결과}

\subsection{Cantilever Wire Probe 인장강도 측정 결과}

4종 Wire probe의 인장강도 측정결과는 다음 Fig. 4 와 같다. 4종 프로브 Wire 인장강도는 $\mathrm{W}, \mathrm{ReW}$, $\mathrm{BeCu}$ 그리고 $\mathrm{P} 7$ 이 각각 2.2-2.3, 1.9-2.3, 0.670.96 그리고 $1.2-1.3 \mathrm{GPa}$ 이였다. 인장강도는 $\mathrm{W}$ 과 $\mathrm{ReW}$ 와이어가 $\mathrm{Cu}$ 또는 $\mathrm{Ag}$ 가 첨가된 와이어 보다 더 크게 측정된 반면, 인성과 연신율은 $\mathrm{BeCu}$ 와 $\mathrm{P} 7$ 와이어 가 더 높게 측정되었다. Fig. 5에서와 같이, $\mathrm{W}$ 과 $\mathrm{ReW}$ 의 경우 취성파괴 및 연성-취성이 혼합된 파괴모드를 나 타내고 있었으며, $\mathrm{BeCu}$ 는 연성파괴 면을 형성하였고, $\mathrm{P} 7$ 의 경우에는 취성파괴가 더 많이 발생된 것을 알 수 있었다. 이것으로 보아 프로브 카드가 반복적인 $\mathrm{T} / \mathrm{D}$ 평가 중 적절한 피로강도와 피로 싸이클을 갖는 Wire probe 소재를 선정하는 것이 중요한 것으로 판단된다.

\subsection{Scrub Mark 분석결과}

Wire probe 소재에 따른 Scrub mark의 크기를 비 교한 결과, Fig. 6과 같이 W, ReW, $\mathrm{BeCu}$ 그리고 P7 이 각각 $12.5,25.6,32.3$ 그리고 $61.7 \mu \mathrm{m}$ 로 측정되

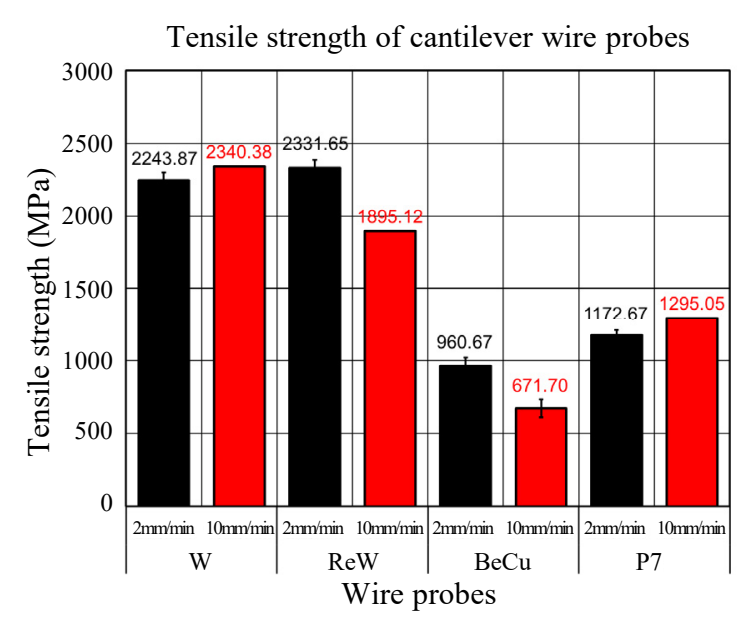

Fig. 4 Tensile strength of 4 kinds of cantilever wire probes with test speed
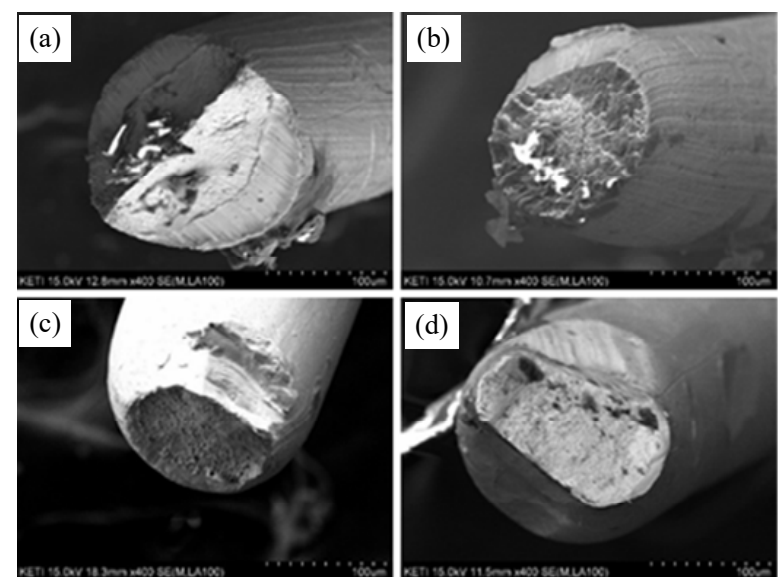

Fig. 5 Fracture surface SEM images of cantilever wire probes after tensile test, (a) W, (b) $\mathrm{ReW}$, (c) $\mathrm{BeCu}$ and (d) P7

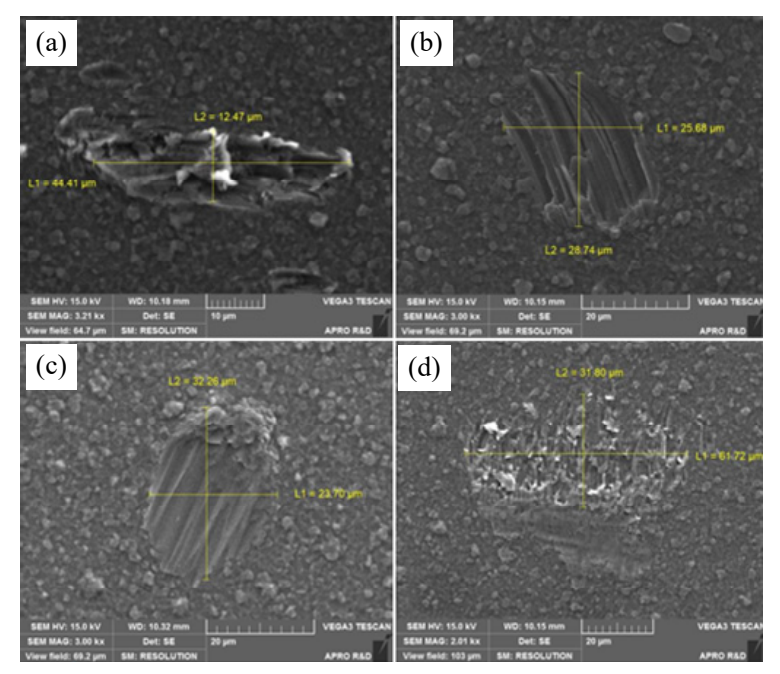

Fig. 6 SEM micrographs of scrub mark generated on the diode surface after 1 cycle T/D test, (a) W, (b) $\mathrm{ReW}$, (c) BeCu and (d) P7

었다. 이것은 앞서 인장강도 측정결과 강도가 높고, 취 성파괴 양상을 보인 $\mathrm{W}$ 또는 $\mathrm{ReW}$ 이 $\mathrm{T} / \mathrm{D}$ 측정 중 Diode 표면에 Scrub mark를 최소로 유발하는 것으로 나타났다. 반면 $\mathrm{Cu}$ 원소가 함유된 와이어 소재의 경우, Scrub mark 길이가 더 길게 나타났으며, 와이어 소재 의 Diode 표면 오염도 더 많이 발생 되는 것을 알 수 있었다. 따라서 $\mathrm{W}$ 또는 ReW 소재가 Scrub mark 발 생 억제에 유리한 것으로 나타났다.

\subsection{Cantilever Wire의 Touch-down 피로시험 후 미세조직}

Cantilever wire의 $-80 \mu \mathrm{m}$ 변위를 인가하는 $\mathrm{T} / \mathrm{D}$ 10 만 회 시험 후 와이어 Bending 부의 굽힘각도를 측 정한 결과 Fig. 7 과 같다. $\mathrm{W}$ 와이어는 $102^{\circ}, \mathrm{ReW}$ 은 


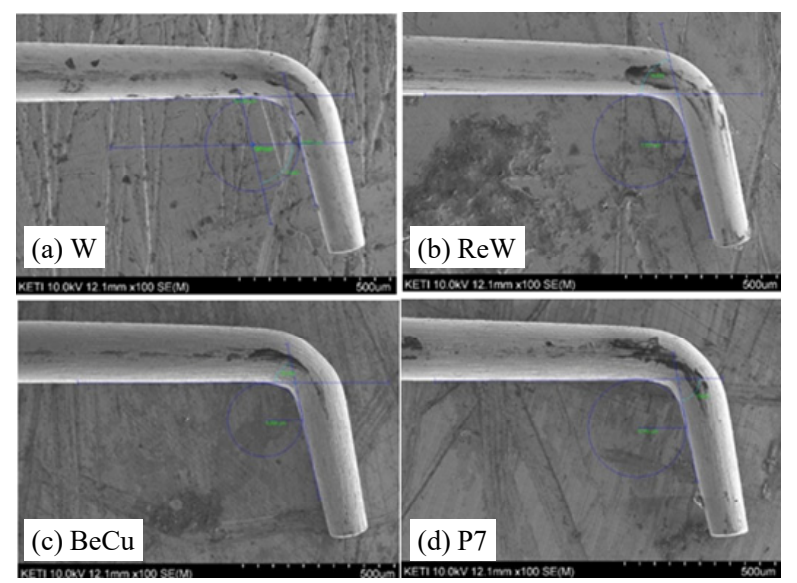

Fig. 7 SME images of cantilever wire probes after 100,000 cycles T/D fatigue test, (a) W, (b) $\mathrm{ReW}$, (c) $\mathrm{BeCu}$ and (d) P7

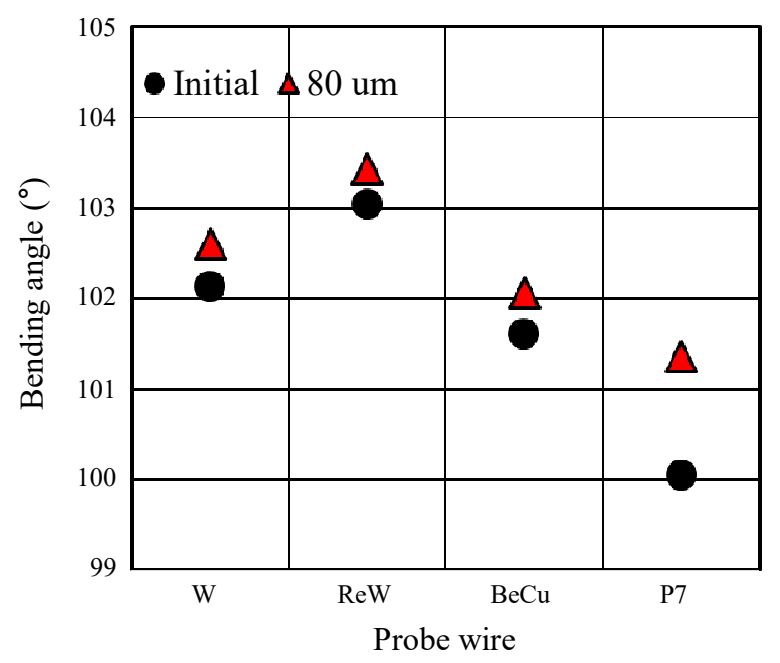

Fig. 8 Bending angle comparison of cantilever wire probes before and after 100,000 cycles T/D fatigue test

$103^{\circ}-104^{\circ}, \mathrm{BeCu}$ 와 $\mathrm{P} 7$ 은 각각 $102^{\circ}$ 와 $100-102^{\circ}$ 로 측정되었다. 이것으로 보아, $\mathrm{T} / \mathrm{D}$ 피로시험 후 가장 많 은 와이어 변형을 나타낸 것은 $\mathrm{P} 7$ 소재였고, 그 다음으 로 $\mathrm{BeCu}$ 소재의 와이어가 변형이 큰 것으로 나타났다. 이것은 앞선 인장강도 평가 결과와 비교할 때, 와이어 프로브 소재의 연신율이 크고, 인장강도 낮은 $\mathrm{BeCu}$ 와 P7 소재에서 와이어 Bending 부 변형이 더 크게 발생 된 것을 알 수 있었다.

Fig. 9는 Wire probe의 10만 회 T/D fatigue test 후, Wire probe의 Bending 부에 대한 SEM 사 진 및 $\mathrm{EBSD}$ 분석결과 이다. 와이어 Bending 부에 가 해진 반복적인 인장 응력에 의해 변형된 미세조직의 변 화를 IPF images와 GROD maps 그리고 Strain contouring maps를 이용하여 비교분석 하였다. IPF scanning images는 하나의 grain orientation에 대
한 Misorientation 영역을 관찰할 수 있으며, Grain refinement나 Deformation된 영역을 구별할 수 있 다. EBSD strain contouring map은 Locallized misorientation 영역을 기반으로 소성변형 (Plastic deformation) 영역을 찾을 수 있으며, 국부적으로 가장 큰 소성변형이 발생된 영역을 찾을 수 있다. 또한 $\mathrm{EBSD}$ GROD scanning을 통해서는 잔류응력 (Residual stress) 영역을 구별할 수 있으며, Grain misorientation 각 도와 모든 Grain의 평균적인 Grain orientation 축 과의 관계를 알 수 있다. 이러한 $\mathrm{EBSD}$ scanning 분 석을 통해 Wire probe의 Bending 부위에 대한 변형 된 미세조직을 정성적으로 비교한 결과를 Fig. 9에 나 타내었다. Fig. $9(\mathrm{a})$ 와 $(\mathrm{d}-\mathrm{k})$ 는 W, Fig. $9(\mathrm{~b})$ 와 $(\mathrm{i}-\mathrm{s})$ $\mathrm{ReW}$, 그리고 Fig. 9 (c) and $(\mathrm{t}-\mathrm{a} \alpha)$ 는 P7 Wire probe의 10 만 회 $\mathrm{T} / \mathrm{D}$ 시험 전후의 $\mathrm{SEM}$ 및 $\mathrm{EBSD}$ 분석 결과이다. 각각의 시편의 결과에서와 같이, 시험 전에 비해 Bending 부의 grain이 인장 (Elongation) 된 것을 알 수 있었다. 이것은 반복적인 $\mathrm{T} / \mathrm{D}$ 시험에 의해 굽힘부에 가해진 응력에 의해 $\mathrm{X}$-축 길이방향으로 인장된 것을 확인하였다. 초기 grain을 비교할 때, $\mathrm{ReW}$ 과 P7 와이는 Equiaxied grain 이였으나, 시험 후 Elongated grain으로 변형된 것을 확인할 수 있었다. 또한 Strain contouring map 분석결과에서도 Bending 부에 misorientation grain이 더 많이 존재함을 알 수 있었다. $\mathrm{W}$ 와이어의 경우, 다른 와이어 미세조직에 비해 시험전 grain이 긴 것을 알 수 있었으나, $\mathrm{T} / \mathrm{D}$ 시험후에는 Grain이 더욱 길게 신축된 것을 확인 할 수 있었다. 이러한 Grain elongation에 대한 피로 저 항성은 인장강도가 높은 것 보다는 파괴인성이 큰 소재 에서 피로응력에 대한 저항성이 더 높게 나타나게 된 다. 따라서 기본적인 항복강도가 높은 $\mathrm{W}$ 과 $\mathrm{ReW}$ 에서 Grain elongation에 의한 misorientation과 strain 발생에 의한 deformation이 작은 반면, 기본적인 항 복강도가 낮은 소재에서는 grain orientation 변형에 의한 strain 발생 양이 더 많은 것으로 판단된다 ${ }^{3-8)}$. 따라서 Toch-down fatigue 특성에 우수한 것은 초기 항복강도가 높은 것 보다는 장시간 사용한 후 와이어 프로브의 변형량이 작게 발생되는 $\mathrm{ReW}, \mathrm{W}, \mathrm{BeCu}$ 소 재가 P7 소재에 비해 우수한 것으로 판단된다.

\section{4. 결 론}

본 연구에서는 4종의 $\mathrm{W}, \mathrm{ReW}, \mathrm{BeCu}$ 그리고 $\mathrm{P} 7$ 합금을 사용한 Cantilever wire probe의 인장강도와 Scrub mark 특성을 측정하고, $\mathrm{T} / \mathrm{D}$ fatigue 시험에 따른 Wire의 피로특성 및 미세조직 변화를 SEM과 


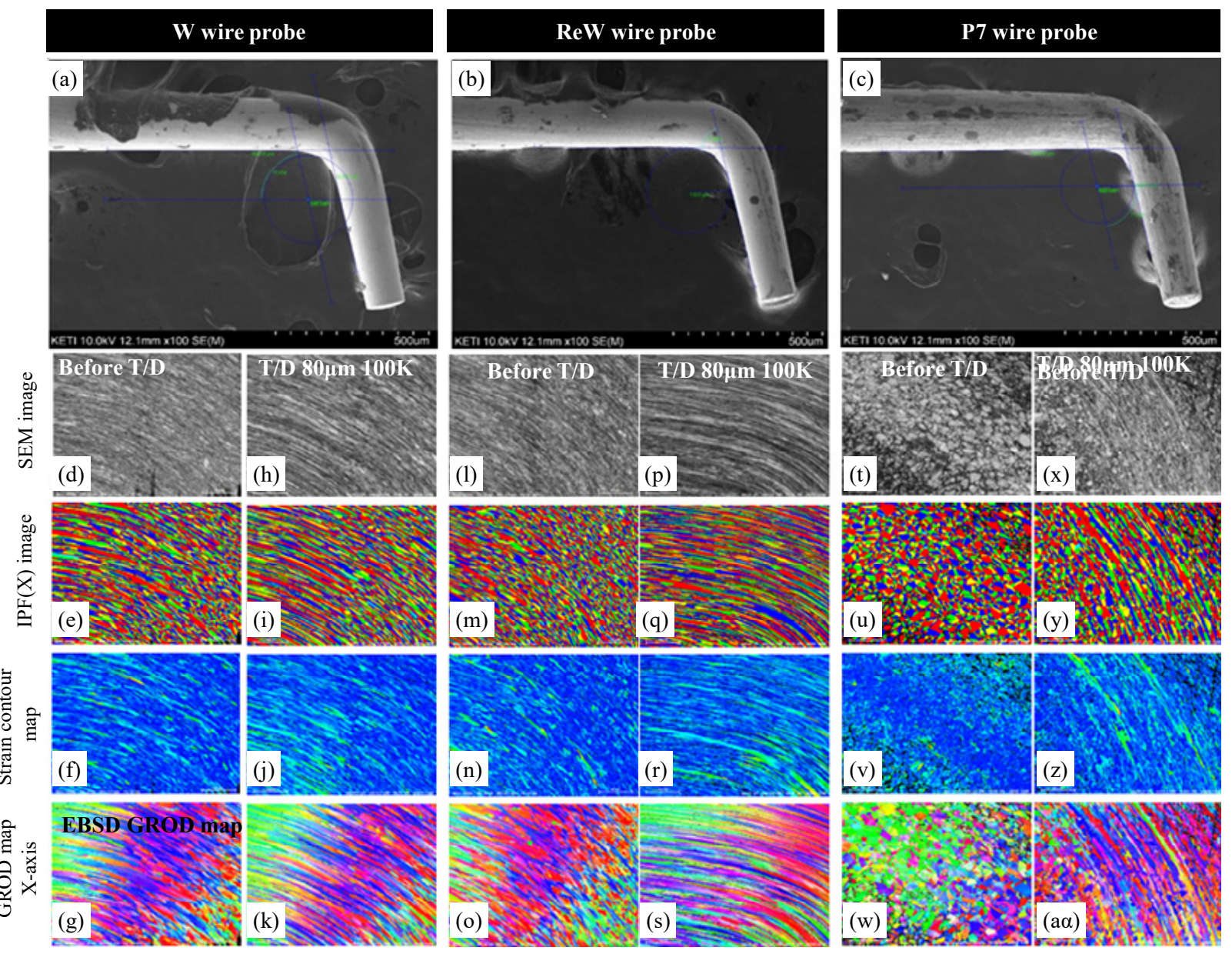

Fig. 9 SEM images and EBSD analysis results of bending area of cantilever wire probes after 100,000 cycles T/D fatigue

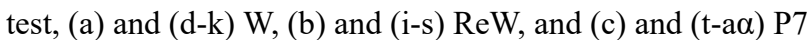

EBSD scanning 분석을 통해 정량적으로 비교분석 하 였으며, 그 결과는 다음과 같다.

1) 와이어 프로브의 인장강도 측정결과 W과 $\mathrm{ReW}$ 소재가 높게 나타났고, $\mathrm{Cu}$ 또는 $\mathrm{Ag}$ 가 첨가된 와이어 에서는 인장강도는 다소 감소하였지만, 인성과 연신율 은 증가된 것으로 나타났다. $\mathrm{W}$ 과 $\mathrm{ReW}$ 의 경우 취성파 괴 및 연성-취성이 혼합된 파괴모드를 나타내고 있으 며, $\mathrm{BeCu}$ 는 연성파괴 면을 형성하였고, $\mathrm{P} 7$ 의 경우에 는 취성파괴가 더 많이 발생된 것을 알 수 있었다.

2) Cantilever wire의 10 만 회 T/D 시험 후 와이 어 Bending 부의 굽힘각도를 측정한 결과 가장 많은 변형을 나타낸 것은 $\mathrm{P} 7>\mathrm{BeCu}$ 순 이였다. 항복강도 결과와 비교할 때 와이어 소재의 연신율 크고, 인장강 도 낮은 $\mathrm{BeCu}$ 와 $\mathrm{P} 7$ 소재에서 와이어 Bending 부 변 형이 더 크게 발생된 것을 알 수 있었다.

3) Wire probe 소재의 초기 항복강도가 높은 W과 ReW Wire probe에서 P7 보다 Grain elongation에 의한 mis-orientation angle이 더 작게 변형하였으며, 이에 따라 strain 발생에 의한 grain deformation이
작은 반면, 초기 항복강도가 낮은 소재에서는 grain orientation 변형에 의한 strain 발생 양이 크게 나타 났다. 따라서 장기적인 $\mathrm{T} / \mathrm{D}$ 사용조건에서는 초기 인장 강도가 높은 것 보다 장시간 사용한 후 변형양이 적게 발생되는 $\mathrm{ReW}, \mathrm{W}$ 그리고 $\mathrm{BeCu}$ 가 $\mathrm{P} 7$ 와이어 소재에 비해 더 우수한 것으로 판단된다.

$$
\text { 후 기 }
$$

본 연구는 산업통상자원부에서 지원한 소재부품기술개 발사업 (과제번호: 20009828)의 지원으로 수행된 연구 결과 입니다.

ORCID: Won Sik Hong: http://orcid.org/0000-0001-8398-177X ORCID: Mi-Song Kim: https://orcid.org/0000-0002-4717-9365

ORCID: Myeongin Kim: https://orcid.org/0000-0002-5151-1404

\section{References}

1. Korea Institute of Science and Technology Information (KISTI), Technical Tren of Semi-conductor Measurement 
and Inspection Equipment, The Ministry of Trade, Industry and Energy (MOTIE) and Materials \& Component Technology Network (MCT-Net), Accessed on https:// www.mctnet.org (2020).

2. W. S. Hong, M. S. Kim, M. Kim, S. H. Yun, and Y. Park, Laser Soldering Properties of MEMS Probe for Semiconductor Water Testing, J. Weld. Join. 39(4) (2021) 368-375. https://doi.org/10.5781/JWJ.2021.39.4.4

3. A. Palaniappan, L. Li, and T.-K. Lee, Impact of Pressfit Connector Pin Microstructure Elastic Response to PCB Through-hole $\mathrm{Cu}$ Wall Interface Long-term Contact Reliability, Proc. 2018 IEEE 20th Electron. Packag. Techol. Conf. EPTC 2018, 890 (2018). https://doi.org/10.1109/EPTC.2018.8654324

4. Y. J. Baek, A. Palaniappan, G. Baty, L. Li, S. K. Hyun, and T. K. Lee, Impact of Thermal Cycling on Cu PressFit Connector Pin Interconnect Mechanical Stability, $J$. Electron. Mater. 50(11) (2021) 4991-4998.
5. L.N. Brewer, D.P. Field, and C.C. Merriman, Mapping and Assessing Plastic Deformation Using EBSD, Electron Backscatter Diffraction in Materials Science., ed. A.J. Schwartz, M. Kumar, B.L. Adams, and D.P. Field (US, Boston, MA: Springer, 2009) 251-262. https://doi.org/10.1007/s11664-021-09045-w

6. S. Kim, W. S. Hong, H. Nam, and N. H. Kang, Growth Behavior of Intermetallic Compounds in Various Solder Joints Induced by Electromigration, J. Weld. Join. 39(1) (2021) 89-102. https://doi.org/10.5781/JWJ.2021.39.1.11

7. W. S. Hong and C. Oh, PoF Based Accelerated Life Prediction with 3 Dimensional Packaging Technology Development, J. Korean Weld. Join. Soc. 27(3) (2009) 10-16.

8. W. S. Hong and C. M. Oh, Thermal Shock Reliability of Low Ag Composition Sn-0.3Ag-0.7Cu and Near Eutectic Sn-3.0Ag-0.5Cu Pb-free Solder Joints, J. Korean Inst. Met. Mater. 47(12) (2009) 842-851. 